\title{
Video-Based Learning Habits of General Surgeons in Turkey: A Survey Study
}

\section{Türkiye'deki Genel Cerrahların Video Tabanlı Öğrenme Alışkanlıkları: Anket Çalışması}

Tevfik Kıvılcım Uprak, Sabri Alper Karataş, Mümin Coşkun

Marmara University, Department of General Surgery, İstanbul, Turkey

\begin{abstract}
$\ddot{O} Z$
GIRIŞ ve AMAÇ: Genel cerrahi eğitiminde, multimedya tabanl eğitim kullanımı sınırlıdır. Çoğu cerrah, özellikle cerrahi asistanlı̆̆ sonrası devam eden eğitimleri için cerrahi videoları izlemek veya yayınlamak için farklı platformlar kullanır. Bu anket çalıșması ile genel cerrahlar arasında video kaynakları kullanma alışkanlıkların incelemesi planlanmaktadır.
\end{abstract}

YÖNTEM ve GEREÇLER: Google anketiyle hazırlanan 28 soru Türk Cerrahi Derneği'nin posta duyuru sistemi araclliğtyla genel cerrahlara gönderildi. Demografik özellikler, cerrahi video ve eğitim perspektifleri, video görüntüleme platformları, ideal video özellikleri sorgulandl.

BULGULAR: Soruları 212 cerrah yanttladı. Güncel yayınlar ve ders kitapları öğrenme için iki temel güvenilir kaynaktır.Cerrahların büyük kismı online video kaynaklardan faydalandı̆̆ını ifade etti. Websurg, web tabanlı ögrenme için bir numaralı kaynak olarak tercih edilirken ve onu Youtube ve Türk Cerrahi Derneği web sitesi takip etmekteydi.

TARTIŞMA ve SONUÇ: Sonuç olarak, cerrahların büyük çoğunluğu bir video platformunu takip etmektedir. Ancak yeni bilgi veya teknik öğrenmek için özellikle güncel yayınları izlemektedirler. Ancak ilerleyen teknoloji ile birlikte video bazl ögrenme önem kazanmaktadır. Anlaşılır ve güvenilir video kaynakları olușturmak, uzmanlık sonrası devam eden eğitiminde etkili bir yöntem olabilir.

Anahtar Kelimeler: yetkinlik bazlı eğitim, genel cerrahi eğitimi, eğitim teknolojisi

\section{ABSTRACT}

INTRODUCTION: In general surgery training, the use of multimedia-based training is limited. Most surgeons use different platforms to watch or broadcast surgical videos for their ongoing training, particularly after surgical residency. This survey study is planned to examine the habits of using online resources (like video platforms) among general surgeons.

METHODS: Twenty-eight questions prepared with the Google survey were sent to general surgeons through the Turkish Surgical Society's mail system and announcement system. Demographic features, surgical video and educational perspectives, video viewing platforms, ideal video features were questioned.

RESULTS: Two hundred twelve surgeons answered the questions. The majority were men. About half of them employed in an academic center. Current publications and textbooks are the two main reliable resources for learning.The Websurg is the number one resource for web-based learning, followed by the YouTube and Turkish Surgical Society website.

DISCUSSION AND CONCLUSION: As a result, the vast majority of participants follow a video platform. However, they especially monitor current publications to learn new information or techniques. Recording and watching videos have gained importance. By creating understandable and reliable video resources, an effective asset can be created in surgeons' ongoing training in the post-residency process.

Keywords: competency-based education, general surgery education, educational technology

\section{İletișim / Correspondence:}

Tevfik Kıvllcım Uprak

Marmara University, Department of General Surgery, Istanbul, Turkey k_uprak2002@yahoo.com

Basvuru Tarihi: 16.01.2021

Kabul Tarihi: 26.08.2021
Doi: $10.5505 / \mathrm{ktd} 2021.01033$

Tevfik Klvilcum Uprak: 0000-0002-6480-7431

Sabri Alper Karataș: 0000-0001-7476-6744

Mümin Coşkun: 0000-0002-0021-8304 


\section{INTRODUCTION}

During the surgical training, various methods have been developed to keep the training uninterrupted due to the lack of time. There are multiple studies about Video-based learning, especially in laparoscopy cases (1,2). Many different teaching modalities like simulators and teaching boxes, and video models are introduced. Especially in the training of laparoscopic surgeries, video-based learning, surgical box, and simulators have been used successfully (3-6).

Online learning methods implemented in medical educational settings have been studied among medical students and residents. Thus beneficial effects have been shown $(7,8)$.

However, there is no certain information about which methods the specialists adopted after surgical training. Among surgeons, it is unknown how frequently videos are used compared to other preparation methods, such as reading textbooks, simulator, etc. Despite there are many studies about different video source platforms used by surgeons. They generally pointed for quality of video sorts (9-11).

We aimed to evaluate video-based learning awareness among general surgeons and assess their opinion about the educational resources, especially in video-based learning. This study's additional purpose was to determine which video resources were used by surgical specialists and what should be in an ideal surgical video.

\section{MATHERIAL AND METHODS}

A virtual questionnaire using Google Forms was prepared and sent to surgeons registered in the Turkish Surgical Society in June 2019 via the weekly newsletter. There were 28 questions in the questionnaire. The demographic characteristics of the participants, the surgical sub-specialization, opinions about surgical videos over the internet, and the effects of surgical videos on surgical training/practice were questioned. The questions were developed in Turkish but are provided in English for the purpose of this publication. The survey was designed by authors. All of the questions were multiple choice.

Participants were also asked questions about learning resources. The use of social media, the resources on video-based learning, the techniques they learned through this media, whether they used these methods in practice and had a video library about surgical procedures were questioned.

At the end of the survey, questions about what an ideal surgical video should be like investigated. Also, opinion was taken on whether the videos should be used in surgical training.

All responses were received anonymously. Incentives such as payments or gifts were not offered to the participants. The results were classified by percentage distribution, and descriptive statistics were given. The study has been approved by the Ethics Committee of Marmara University University School of Medicine.

\section{Table 1. Demographic features of Participants}

\begin{tabular}{|l|l|}
\hline \hline Age & \\
\hline$<34(\%)$ & $35(16,6)$ \\
$35-44(\%)$ & $80(37,9)$ \\
$45-60(\%)$ & $73(34,1)$ \\
$60+(\%)$ & $24(11,3)$ \\
\hline Sex & \\
(Male/Female) & $197 / 15$ \\
\hline Occupation & \\
Consultant (\%) & $111(52)$ \\
Faculty Member (\%) & $101(48)$ \\
\hline Employment & \\
Primary or secondary center and private & $94(44)$ \\
hospital (\%) & \\
\hline Tertiary Hospital (\%) & \\
\hline Multiple options are marked. & \\
\hline Hransplantation & \\
\hline Specialization ${ }^{\text {a }}$ & \\
\hline
\end{tabular}




\section{RESULTS}

212 surgeons responded to the survey. Demographic features were shown in table 1.

As one of the two most reliable sources, $61.9 \%$ of current publications and articles, $56.7 \%$ of textbooks were observed. Only $19.5 \%$ of participants considered video sharing sites as a reliable resource. $85.6 \%$ of the participants followed surgery video sharing sites, and preferred online resources were Websurg, YouTube, and Turkish Surgical Society web page, respectively, $(67 \%, 65.6 \%, 60.6 \%)$. Most of the participants (\%93) prefer videos because they are easy to understand, visual, and detailed.

It was determined that $41 \%$ of the participants applied to current publications for the purpose of learning new information and surgical techniques.

Although $72 \%$ of the participants check the technique or information from a colleague's opinion, 50\% stated that they could use and apply this knowledge and technique without a supervisor.

$61.4 \%$ of the surgeons surveyed that they record their own surgical procedures. It was understood that while $21.2 \%$ were recorded for watching, $29.6 \%$ were recorded for archiving, and $10.6 \%$ were preferred to share videos on social media. $80.2 \%$ of participants follow professional surgical posts on social media. However, only $33.3 \%$ have social media accounts with professional sharing.

When sharing the videos of the operations in terms of ethics, $64 \%$ thought that they should only be shared with physicians, and $32 \%$ thought that they could share them with everyone, as long as the patient gave consent. When the purpose of watching Surgical/ Intervention videos is questioned, the majority of surgeons (\%70) stated that learning new techniques and not neglecting a rare technique was the main subject. $29 \%$ of the participants watch videos to prepare for complications before surgery.

$56 \%$ of participants mentioned that every detail should be recorded in an ideal video, as a complete record. $\% 70$ of participants preferred video resources as presented in a language they understand. Sharing institution or person and the video platform are the most trustworthy factors for video $\% 58$. Video/shooting quality, recording date were the least reliable criteria for the participant.
$15 \%$ of surveyors retrect that the presenter's credibility, respectability is positively affected by exhibiting own surgical videos in congress/meeting. $67 \%$ of participants recommend residents to watch surgical videos for their training. $72 \%$ of surveyors consider watching surgical videos does not replace being an observer in surgery because it is not interactive.

\section{DISCUSSION}

This national survey demonstrates that the majority of surgeons follow the surgical video content up-to-date and monitor the Turkish Surgical Society's website as well as the popular international websites such as YouTube and Website.

To our knowledge, this is the only national survey study that has ever been accomplished among general surgeons in this respect.

Most training materials for surgical residents rely on textbooks. However, text-based educational materials have natural limitations because the real three-dimensional surgical field is hard to fully understand. As a result, the requirement for video teaching materials recorded during surgeries has been increasing. With the development of laparoscopic surgery, more information can be transmitted through video than video-based texts (1).

In this study, $41 \%$ of surgeons still prefer articles and current publications searching for new - up to date information. This may be due to historical habits, the diversity of video sources, and not proven reliability of these resources. In a national study among surgical residents in the United States, it has been shown that the trainee preference for exam preparation was still textbooks. Participants believed that mobile applications for patient care had gained popularity. Residents could better incorporate simulation if the simulation equipment was functional and structured feedback/supervision is available during training sessions (12). Elearning has been compared with experts on various platforms and shown to be equally successful. It has been proposed to integrate with traditional materials due to many advantages, such as a lesson reserved for a limited time and a feedback session, always continuing education, applying less geographical 
and temporal restrictions for both staff and students $(3,13,14,15)$.

Another survey from Australia in a small sample size showed that most surgeons believe education in operating theatre is most valuable than web-based laparoscopic learning. However, e-learning methods has gained acceptance among surgeons and trainees (16). In a similar manner, in this study, two-thirds of the surgeons stated being an observer in a surgical operation is better rather than watching surgical videos. Although the majority of surgeons checked a technique or information obtained from these videos, because of safety purposes, half of them indicated that they could apply a technique they had just learned without a supervisor.

Review, which mostly includes residents and medical students, resulted that video-based learning can shorten the learning curves of the trainees (17). In 2009, Pugh et al. have been concluded that the strong capabilities of the Internet have led to the rapid inclusion of web-based training tools in surgical training and practices. Web-based learning makes great promises to address current challenges caused by surgical training time constraints and patient safety concerns(18). The videos recorded during the surgery are considered to be used in education and even as an examination method. However, it is stated that high quality, narrative and edited videos are more informative for residents' education $(19,20)$.

Recently, surgical videos are accessible with the innovation of video streaming services like YouTube, ORlive, Websurg etc., more easily than ever before. Many advances in this area make it possible to reach online resources on social media also (21).

In this study, three main sources as Youtube, Websurg, and Turkish Surgical Society web page, were specified as main surgical video resources.

Survey study from the United States showed that many residents and medical students who pursued surgery preferred the YouTube and Score portal system. Authors indicate that peer review and standardized, easy accessed videos need to be posted in the future for learners maximal benefit (22).

Some reports that assessed the educational quality of YouTube videos on different specialty and regarded as educationally useful $(9,10)$. If the YouTube content is selected carefully and precisely, it can be presented as an active didactic method as a teaching skill or discussion platform(11). In this study, over half of the surgeons specify that detailed and understandable language is key for the ideal video.

YouTube could have a supplementary role but should be used with approved instructional material. Universities should ensure their own videos and students were taught to review videos critically (23).

Therefore, reliability scales of videos for many surgical techniques have been investigated in recent years. In this study revealed that the platform and the sharing institution are the most effective factors for assessing the reliability of videos. There are many publications evaluating videos about general surgical procedures on YouTube. Videos uploaded by tertiary centers show the highest education rate. however, there is a lack of standardized guidance in video assessment $(24-26,27)$.

Despite the advantages of e-learning, instructional design, social isolation, and technical problems were described as a potential problem in e-learning modalities (15). Besides these, live surgery model provides a large number of observers without increasing the number of people in the operating room. It can be used in surgical education in various branches, especially in low-income countries $(28,29)$.

The original, unedited recording should ideally be kept if it is to be used for medicolegal defense. The surgeon should be aware of the problem in storage and the security of video data (23). For a similar perspective, one third of the surgeons, surveyed that purpose of watching surgical videos as education for possible perioperative complications. Over \% of 60 surgeons recorded their surgical procedure. Procedure videos can be analyzed in morbidity and mortality meetings. Moreover, video files' exportability can facilitate external review and allow a peer reviewer from a local department's policy to advise on what can be improved (30). There are various methods for selfassessment among surgeons. The accuracy of selfassessment was increased significantly by video playback analysis. This supports the recommendation that self-assessment may be developed after review their video recorded performance $(31,32)$. Two thirds of surgeons identified that using their own video during the 
presentation at the conference improves the quality and reliability of the presentation. This is another advantage of recording a surgical video.

\section{Limitations}

According to the Turkish Surgical Society, it is known that there are more than 5000 surgeons in the country. In our study, the number of responses was 200, and this was representing approximately $4 \%$ of all surgeons with a low threshold. Since there is no defined survey on this subject, a survey was prepared by the authors. These are the limitations of the study.

\section{CONCLUSION}

Surgeons still prefer current articles and textbooks to gain insight into new knowledge or technique. However, video watching habits are getting more and more popular. Aside from learning new knowledge, medicolegal and various advantages of video surveillance and recording draw the attention. Therefore, understanding surgeons' views on surgical video education can be used to develop applications or investments to be created in this regard.

Ethics Committee Approval: Marmara University Health Sciences Ethics Committee(14.09.2020 date and 72 number)

Conflict of Interest: There is no conflict of interest.

Funding: There is no financial support.

Informed Consent: Patient consent was obtained.

\section{REFERENCES}

1.Ahmet A, Gamze K, Rustem M, Sezen KA. Is Video-Based Education an Effective Method in Surgical Education? A Systematic Review. J Surg Educ [Internet]. 2018;1-9. Available from: http://dx.doi.org/10.1016/j.jsurg.2018.01.014

2.Jayakumar N, Brunckhorst O, Dasgupta P, Khan MS, Ahmed K. E-Learning in Surgical Education:
A Systematic Review. J Surg Educ. 2015;72(6):1145-57.

3.Stefanidis D, Korndorffer JR, Heniford BT, Scott DJ. Limited feedback and video tutorials optimize learning and resource utilization during laparoscopic simulator training. Surgery. 2007;142(2):202-6.

4.Madan AK, Frantzides CT. Substituting virtual reality trainers for inanimate box trainers does not decrease laparoscopic skills acquisition. JSLS. 2007;11(1):87-9.

5.Munz Y, Kumar BD, Moorthy K, Bann S, Darzi A. Laparoscopic virtual reality and box trainers: Is one superior to the other? Surg Endosc Other Interv Tech. 2004 Mar 2;18(3):485-94.

6.Mohammadi Y, Lerner MA, Sethi AS, Sundaram CP. Comparison of laparoscopy training using the box trainer versus the virtual trainer. $\mathrm{J}$ Soc Laparoendosc Surg. 2010 Apr;14(2):205-12.

7.Sinkov VA, Andres BM, Wheeless CR, Frassica FJ. Internet-Based Learning. Clin Orthop Relat Res. 2004;(421):99-106.

8.Bernardo V, Ramos MP, Plapler H, De Figueiredo LFP, Nader HB, Anção MS, et al. Webbased learning in undergraduate medical education: Development and assessment of an online course on experimental surgery. Int $\mathrm{J}$ Med Inform. 2004;73(9-10):731-42.

9.de'Angelis N, Gavriilidis P, Martínez-Pérez A, Genova P, Notarnicola M, Reitano E, et al. Educational value of surgical videos on YouTube: quality assessment of laparoscopic appendectomy videos by senior surgeons vs. novice trainees. World J Emerg Surg [Internet]. 2019 Dec 9 [cited 2019 Jul 20];14(1):22. Available from: https://wjes.biomedcentral.com/articles/10.1186/s13 017-019-0241-6

10.Frongia G, Mehrabi A, Fonouni H, Rennert H, Golriz M, Günther P. YouTube as a Potential 
Training Resource for Laparoscopic Fundoplication. J Surg Educ [Internet]. 2016;73(6):1066-71. Available from: http://dx.doi.org/10.1016/j.jsurg.2016.04.025

11.Fischer J, Geurts J, Valderrabano V, Hügle T. Educational quality of YouTube videos on knee arthrocentesis. J Clin Rheumatol. 2013;19(7):37312.Glass NE, Kulaylat AN, Zheng F, E. Glarner C, Economopoulos KP, Hamed $\mathrm{OH}$, et al. A national survey of educational resources utilized by the Resident and Associate Society of the American College of Surgeons membership. Am J Surg [Internet]. 2015;209(1):59-64. Available from: http://dx.doi.org/10.1016/j.amjsurg.2014.09.016

13.Xeroulis GJ, Park J, Moulton CA, Reznick RK, LeBlanc V, Dubrowski A. Teaching suturing and knot-tying skills to medical students: A randomized controlled study comparing computer-based video instruction and (concurrent and summary) expert feedback. Surgery. 2007;141(4):442-9.

14.Nousiainen $M$, Brydges $R$, Backstein $D$, Dubrowski A. Comparison of expert instruction and computer-based video training in teaching fundamental surgical skills to medical students. Surgery. 2008;143(4):539-44.

15.Evgeniou E, Loizou P. The theoretical base of elearning and its role in surgical education. J Surg Educ [Internet]. 2012;69(5):665-9. Available from: http://dx.doi.org/10.1016/j.jsurg.2012.06.005 16.Egedovo A, Ho Y-H, Larkins S, Mushuya C, Ashraf M, Nyandowe M, et al. Awareness of surgeons and surgical trainees of online web-based techniques for teaching laparoscopic surgery in north Queensland. Int Surg J [Internet]. 2017 Jun 22 [cited 2019 Jul 20];4(7):2131-8. Available from: https://www.ijsurgery.com/index.php/isj/article/vie w/1450/1262

17.Pape-Koehler C, Immenroth M, Sauerland S, Lefering $\mathrm{R}$, Lindlohr $\mathrm{C}$, Toaspern $\mathrm{J}$, et al.
Multimedia-based training on Internet platforms improves surgical performance: A randomized controlled trial. Surg Endosc [Internet]. 2013 May 9;27(5):1737-47. Available from: http://link.springer.com/10.1007/s00464-012-2672$\mathrm{y}$

18.Pugh CM, Watson A, Bell RH, Brasel KJ, Jackson GP, Weber SM, et al. Surgical Education in the Internet Era1. J Surg Res. 2009;156(2):177-82. 19.Lee SA, Lee J-M, Suh K-S, Hong S-K, Cho J-H, Yi N-J, et al. Wearable recording video technology for surgical training in living donor liver transplantation. Ann Hepato-Biliary-Pancreatic Surg [Internet]. 2020;24(1):38. Available from: http://10.0.57.109/ahbps.2020.24.1.38

20.Abdelsattar JM, Pandian TK, Finnesgard EJ, El Khatib MM, Rowse PG, Buckarma EH, et al. Do You See What i See? How We Use Video as an Adjunct to General Surgery Resident Education. J Surg Educ. 2015;72(6):e145-50. 